\title{
School Counseling Skills Needed To Activate Distance Learning In Light Of Covid-19 Pandemic
}

\author{
AL-halalmeh, $\mathbf{S}$ \\ Dr. Sabreen Tawfeq AL-halalmeh \\ Email-Sabreen19.tawfek@hotmail.com \\ Jordan -Amman
}

Article History: Received: 11 January 2021; Accepted: 27 February 2021; Published online: 5 April 2021

\begin{abstract}
The problem and the aim of the study: COVID-19 pandemic had affected all sectors including the educational sector. The educational system shifted from the traditional face to face teaching method to use online means in order to ensure the safety of the students and the social distancing. These changes also affected the roles of the educational members including the school counselors. Therefore, the study aims to investigate the school counseling skills needed in light of COVID-19.

Research Method: The study relied on the descriptive approach and administrated by a questionnaire to collect the data from the school counselors. The study sample consisted of (400) Jordanian schools counselors from both genders whom chosen randomly to respond to the study tool.

Results: The study found that the main required skills are the cognitive, emotional and humanitarian skills, professional and ethical skills, technical and electronic skills. The study found that the most needed counseling skills are similar to the traditional education, but due to the shift from the from face to face education to the distance education the most concentration will be on the counselors IT skills.
\end{abstract}

Keywords: School counselors, needed skills, online education, Covid-19.

\section{Introduction}

COVID-19 crisis affected the educational systems all over the globe, and forced them to search for alternative instruction methods than the traditional face-to-face. Therefore, the educational systems adopted the online teaching in order to pursue the educational process and to ensure the WHO instructions regarding the social distancing [8]. School counselors are main components in the educational team and can handle also leadership roles [1].

According to Harris \& Hal (1985), the counselors' skills are related to their ability to participate in forming the future of the students, provide them with many experiences, increase their awareness about the problems that the students encounter.

The distance learning school counseling guide indicated that the school counselors shall follow the following points [3]:

1. Adopting similar ethical guidelines of face to face education.

2. Identifying the virtual school counseling skills.

3. Apply some procedures that students shall follow even in the absence of school counselors.

4. Introduce the importance and procedures of distance education for the students and parents.

5. Participate in the students' education on how to use the electronic platforms.

The study [4] indicated the main principles that the counselors shall follow are: (1) Committing to the ethical code such as bearing the responsibility, honest, and patience. (2). Flexibility to hear and accept the students' requirements and problems. (3). Avoid creating personal relationships with the students, and make professional relations. As well, the counselor shall have the personal and professional characteristics including the scientific and specialized knowledge in the field of educational to understand and analyze the students' behavior. Moreover, the school counselors shall develop their skills in the filed by reviewing the scientific and periodic researches. As well, there are vital skills and requirement from the educators and counselors to ensure the validity of online teaching such as specifying times to call the students individually or their parents, using online tools to express the students' attitude and feedback, using the available contact resources to conduct sessions with students in need for mental health services such as telehealth applications, and providing group therapy via online tools for students who encounter family problems. This study focused on the school counseling skills required to activate the distance learning in light of COVID-19 pandemic. This study consists of 400 school counselors. To collect the data the researcher developed a questionnaire to gather the respondents' opinion about the cognitive, emotional, humanitarian, vocational, technical and electronic skills of the counselors in order to activate the distance learning in light of COVID-19 [5]. 


\section{Questions of the study}

1. What are the main cognitive, emotional and humanitarian skills that school counselors shall maintain to activate the distance learning in light of COVID-19 from the counselors' point of view?

2. What are the vocational, technical and electronic skills that school counselors shall maintain to activate the distance learning in light of COVID-19 from the counselors' point of view?

3. Are there statistical significant differences in the counselors' responses at the level attributed to gender, Age, educational level, and experience?

\section{Literature Review}

The study [6] aimed to find the degree of professional skills that social counselors have in the primary schools in Damascus. As well, the study investigated the relationship between the students and counselors, and analyzing these relationships to investigate the counselors' roles in enhancing and promoting the students' skills and future. The study sample consisted of 195 counselors from both genders in Damascus schools. The researcher used the descriptive approach and the social survey, and used a questionnaire to collect the data. The study found that the school counselors lack to the complete awareness of the school counselor roles especially the basic skills. As well, the schools include a high number of students in a manner that reduces the effectiveness of the counselors' role to meet the students' needs and solve their problems. Moreover, the existence of few numbers of counselors in the schools increases their burden in terms of number of students, which shapes constraints for the counselors to operate their tasks. Finally, the educational institutions lack to required abilities to operate their activities that serve the educational objectives.

The study [7] aimed to identify the role of school counselors in relieving some of the students' problems at the elementary stages. The study relied on the descriptive approach. The study sample consisted of 120 students (males and female) and 60 teachers from both genders. The researcher applied the anger measure on the students and a questionaries' on the teachers to collect their opinions. The study revealed that schools are in need for more school counselors, whom have a significant role in relieving some of the students' problems at the elementary stages.

The study [9] aimed to investigate the school counselors' social, vocational, academic, and personal characteristics. The study sample consisted of 49 school counselors that work in Istanbul schools. The researcher used two tools: one a form for personal information and the second for the counselors' services. The study found that schools counselors provide personal services greater than the vocational and academic services.

\section{Methodology \\ Tool}

The study relied on the questionnaires to collect the data from the school counselors. This tool was exposed to jury from the counseling departments, and it was tested on a separated sample of $10 \%$ of the total sample. The study tool involved the Cognitive, emotional and humanitarian skills, Professional and ethical skills, and the Technical and electronic skills.

\section{Study Hypothesis}

- $\quad$ The main cognitive, emotional and humanitarian skills that school counselors shall maintain are not needed to activate the distance learning in light of COVID-19 from the counselors' point of view.

- The vocational, technical and electronic skills that school counselors shall maintain are not needed to activate the distance learning in light of COVID-19 from the counselors' point of view.

- There are no statistical significant differences in the counselors' responses at the level attributed to gender, Age, educational level, and experience.

\section{Research Results Reliability}

Table (1) shows the Cronbach' Alpha value which rang $(0.95-0.97)$, and total questionnaire items was $(0.98)$, this indicate to acceptable Cronbach' Alpha value for each domain, whenever Cronbach' Alpha value is acceptable if it's more than $(0.60)$. 
Table (1) Cronbach' Alpha value for each domain

\begin{tabular}{|c|c|}
\hline Variables & Cronbach' Alpha value \\
\hline Cognitive, emotional and humanitarian skills & 0.95 \\
\hline Professional and ethical skills & 0.97 \\
\hline Technical and electronic skills & 0.97 \\
\hline Total & 0.98 \\
\hline
\end{tabular}

Table (1) indicates that the Cronbach' Alpha value of the Cognitive, emotional and humanitarian skills is (0.95), while Professional and ethical skills (0.97), and the Technical and electronic skills is (0.97), which indicate the study tool is reliable.

\section{Sample of study:}

The study sample consisted of (400) of school counselors, table (2) shows the distribution of the sample depending on the personal and functional variables.

Table (2) Frequency and Percent for the personal and functional variables

\begin{tabular}{|c|c|r|r|}
\hline \multirow{2}{*}{ Variable } & & Frequency & Percent \% \\
& & & \\
\hline \multirow{2}{*}{ Gender } & Male & 115 & 28.7 \\
\cline { 2 - 4 } & Female & 285 & 71.3 \\
\hline \multirow{2}{*}{$\begin{array}{c}\text { Educational } \\
\text { Qualification }\end{array}$} & Bachelors & 129 & 32.3 \\
\cline { 2 - 4 } & Higher Education & 271 & 67.8 \\
\cline { 2 - 4 } Years of Services & 5 years & 76 & 19.0 \\
\cline { 2 - 4 } & $6-10$ years & 57 & 14.2 \\
\cline { 2 - 4 } & $11-15$ years & 76 & 47.8 \\
\hline
\end{tabular}

Table (2) illustrates the frequency and percentage of functional variables of the study sample. Table (2) indicates that the total counselors number is 400 (115 Male and 285 Female), while 129 of them have bachelor degree and 271 have higher education. Finally, the years of services varied from 6-10 years 14.2\%, while 11-15 years was the highest (47.8\%), and more than 15 years $19 \%$.

Question One: What are the main Cognitive, emotional and humanitarian skills needed to activate distance learning in light of Covid-19 Pandemic?

To answer this question, we compute the Means and standard deviations for each item of Cognitive, emotional and humanitarian skills level, table (3) shows that.

Table (3): Means and standard deviations for each item of Cognitive, emotional and humanitarian skills level

\begin{tabular}{|c|c|c|c|c|c|}
\hline No. & Statement & Mean & SD & Order & Importance \\
\hline 1 & $\begin{array}{l}\text { The school counselor should be distinguished by } \\
\text { intelligence and an understanding of the exact field of } \\
\text { scientific specialization: theoretically and practically }\end{array}$ & 4 & 1.16 & 1 & High \\
\hline 2 & $\begin{array}{l}\text { The school counselor should be fluent, flexible, and } \\
\text { open to the world }\end{array}$ & 4 & 1.35 & 2 & High \\
\hline 3 & $\begin{array}{l}\text { The school counselor must possess research and } \\
\text { development skills for his cognitive skills in his field } \\
\text { of work through continuous updating, reviewing } \\
\text { scientific researches, participating in specialized } \\
\text { periodicals, and attending conferences and seminars }\end{array}$ & 3.96 & 1.33 & 3 & High \\
\hline 4 & The school counselor should possess the scientific & 3.81 & 1.3 & 4 & High \\
\hline
\end{tabular}




\begin{tabular}{|c|l|c|c|c|c|}
\hline & $\begin{array}{l}\text { and cognitive skills in his field of work and its } \\
\text { development, preventive and curative services }\end{array}$ & & & \\
\hline Total & 3.94 & 1.20 & --- & High \\
\hline
\end{tabular}

Table (3) shows Cognitive, emotional and humanitarian skills level: the range means for items of this domain is between $(3.81-4.00)$, the higher means for item (The school counselor should be distinguished by intelligence and an understanding of the exact field of scientific specialization: theoretically and practically), but the lower means for item (The school counselor should possess the scientific and cognitive skills in his field of work and its development, preventive and curative services.) Total means was (3.94) by highly agreement.

Question Two: What are the main Professional and ethical skills needed to activate distance learning in light of Covid-19 Pandemic?

To answer this question, we compute the Means and standard deviations for each item of Professional and ethical skills levels, below tables (4) shows that.

Table (4): Means and standard deviations for each item of Professional and ethical skills level

\begin{tabular}{|l|l|c|c|c|c|}
\hline No. & \multicolumn{1}{|c|}{ Statement } & Mean & SD & Order & Importance \\
\hline 1 & $\begin{array}{l}\text { The school counselor should flexible in } \\
\text { dealing with the students, and not to be } \\
\text { bound by specific methods in } \\
\text { understanding their demands and guidance } \\
\text { needs }\end{array}$ & 4.05 & 1.13 & 1 & High \\
\hline 5 & $\begin{array}{l}\text { The school counselor should have the skills } \\
\text { of listening and influencing others }\end{array}$ & 4.05 & 1.25 & 2 & High \\
\hline 4 & $\begin{array}{l}\text { The school counselor should adhere to the } \\
\text { ethics of the counseling profession in word } \\
\text { and deed, and to be an example in bearing } \\
\text { responsibility, patience and honesty }\end{array}$ & 4 & 1.23 & 3 & High \\
\hline 2 & $\begin{array}{l}\text { The school counselor should possess the } \\
\text { emotional control and emotional balance }\end{array}$ & 3.95 & 1.29 & 4 & High \\
\hline 3 & $\begin{array}{l}\text { The school counselor should move away } \\
\text { from restrictiveness and adhere to } \\
\text { professional work ethics }\end{array}$ & 3.86 & 1.46 & 5 & High \\
\hline 6 & $\begin{array}{l}\text { The school counselor should have the } \\
\text { ability to manage dialogues, discussions } \\
\text { and have effective communication skills }\end{array}$ & 3.86 & 1.36 & 6 & High \\
\hline & \multicolumn{1}{|c|}{ Total } & 3.96 & 1.22 & --- & High \\
\hline
\end{tabular}

Table (4) shows S Professional and ethical skills level: the range means for items of this domain is between (3.86 4.05), the higher means for item (The school counselor should flexible in dealing with the students, and not to be bound by specific methods in understanding their demands and guidance needs), but the lower means for item (The school counselor should have the ability to manage dialogues, discussions and have effective communication skills) Total means was (3.96) by highly agreement.

Question Three: What are the main Technical and electronic skills needed to activate distance learning in light of Covid-19 Pandemic?

To answer this question, we compute the Means and standard deviations for each item of the Technical and electronic skills level, table (5) shows that.

Table (5): Means and standard deviations for each item of Technical and electronic skills level

\begin{tabular}{|l|l|c|c|c|c|}
\hline No. & \multicolumn{1}{|c|}{ Statement } & Mean & SD & Order & Importance \\
\hline 4 & $\begin{array}{l}\text { The school counselor should follow up on } \\
\text { students' problems and counseling needs } \\
\text { through group and individual electronic } \\
\text { conversations }\end{array}$ & 3.95 & 1.13 & 1 & High \\
\hline 2 & The school counselor must possess the & 3.81 & 1.3 & 2 & High \\
\hline
\end{tabular}




\begin{tabular}{|c|c|c|c|c|c|}
\hline & $\begin{array}{l}\text { ability to use electronic tools to obtain } \\
\text { student feedback and evaluation of e- } \\
\text { learning on an ongoing basis }\end{array}$ & & & & \\
\hline 6 & $\begin{array}{l}\text { The school counselor should contribute to } \\
\text { enhancing students' commitment to } \\
\text { attending the online lessons }\end{array}$ & 3.81 & 1.18 & 3 & High \\
\hline 1 & $\begin{array}{l}\text { The school counselor must possess the skills } \\
\text { of using smart learning platforms and } \\
\text { applications such as Zoom, Microsoft } \\
\text { Team, and e-learning platforms }\end{array}$ & 3.77 & 1.15 & 4 & High \\
\hline 5 & $\begin{array}{l}\text { The school counselor should partner with } \\
\text { the teachers to raise the morale of students } \\
\text { to study remotely }\end{array}$ & 3.77 & 1.19 & 5 & High \\
\hline 3 & $\begin{array}{l}\text { The school counselor should hold electronic } \\
\text { calls with parents and students to discuss } \\
\text { students' issues }\end{array}$ & 3.43 & 1.22 & 6 & Moderate \\
\hline \multicolumn{2}{|r|}{ Total } & 3.76 & 1.11 & --- & High \\
\hline
\end{tabular}

Table (5) shows Technical and electronic skills level: the range means for items of this domain is between (4.24 3.95), the higher means for item (The school counselor should follow up on students' problems and counseling needs through group and individual electronic conversations), but the lower means for item (The school counselor should hold electronic calls with parents and students to discuss students' issues.) Total means was (3.76) by highly agreement.

\section{Discussion}

Based on the related literature, the most required skills from the school counselors are the cognitive, emotional and humanitarian skills, professional and ethical skills, technical and electronic skills. Among the cognitive, emotional and humanitarian skills, the highest mean item is "school counselor should be distinguished by intelligence and an understanding of the exact field of scientific specialization: theoretically and practically". This result is consistent to [4] which indicated that school counselors shall be intelligent and understand the theoretical and practical aspect of their specialization. Among the professional and ethical skills, the highest means was for the item (The school counselor should flexible in dealing with the students, and not to be bound by specific methods in understanding their demands and guidance needs) (ASCA, 2016). The results also indicated that technical and electronic skills are very important to activate the distance education because it came with a high importance based on the counselors' point of view.

\section{Conclusion}

The present study aimed to investigate the school counseling skills needed to activate distance education from the counselors' point of view. The study focuses on the school counselors skills in general and the newly inserted requirements in light of Covid-19. The study found that the main required skills are the cognitive, emotional and humanitarian skills, professional and ethical skills, technical and electronic skills. All of these skills came in a high importance based on the counselors' point of view because all of them are required to ensure the accurate and adequate delivery of education.

\section{References}

1. Wingfield, Robert J.; Reese, Ryan F.; Olatunji, Cirecie A. West- (2010). Counselors as Leaders in Schools. Florida Journal of Educational Administration \& Policy. 4(1), 114-130.

2. Harris, K. \& Hal pin, G. (1985). Teachers Stress as Related to Locus of Control, Sex \& Age, Journal of Expert Education, 53(3) (1985) , pp.136-140.

3. American School counselor association (ASCA) (2016). Ethical Standards for School Counselors. https://www.schoolcounselor.org/getmedia/f041cbd0-7004-47a5-ba01-3a5d657c6743/EthicalStandards.pdf

4. Abduladeem, Hamdi Abdullah (2014). Counseling and Guidance Skills. Amjad publishing Ltd: Egypt.

5. Bowen, J. (2020, April 14). Counselors and Educators Should Check-in With Students, Prioritize Mental Health and Well-being During Coronavirus (COVID-19) School Closures. College of Education, NC State 
University. https://ced.ncsu.edu/news/2020/04/14/counselors-and-educators-should-check-in-with-studentsprioritize-mental-health-and-well-being-during-coronavirus-covid-19-school-closures/

6. Mustafa, Talal Abdelmuti (2011). Skilled requirements for social counselors in the primary education: field study in Damascus City Schools. Damascus University Journal, 27 (1), 499-533.

7. Faraj Allah, Su'ad (2016). The role of School Counselors in relieving some of the students' problems (fear and anger) at the elementary stages from the teachers point of view. (Masters' Thesis), Mohammad Budyaf University, Algeria.

8. Huber, S. G., \& Helm, C. (2020). COVID-19 and schooling: evaluation, assessment and accountability in times of crises - reacting quickly to explore key issues for policy, practice and research with the school barometer. Educational Assessment, Evaluation and Accountability, 32(2), 237-270. https://doi.org/10.1007/s11092-020-09322-y

9. Yuksel-Sahina, Fulya (2012). School Counselors' Assessment of the Psychological Counseling and Guidance Services they Offer at their Schools. Procedia - Social and Behavioral Sciences, 47 ( 2012 ) 327 -339 . 